\title{
Restoring historical fire regimes increases activity of endangered bats
}

\author{
Elizabeth C. Braun de Torrez ${ }^{1 *}$ (D), Holly K. Ober ${ }^{2}$ and Robert A. McCleery ${ }^{1}$
}

\begin{abstract}
Background: Fire suppression has altered ecological communities globally. Prescribed fire regimes strive to restore function to these fire-dependent ecosystems by mimicking natural fire regimes. Although fire frequency is a widely acknowledged component of fire regimes, the importance of fire seasonality for biodiversity is less clear but appears to play a critical role for a variety of taxa, particularly in the North American Coastal Plain. In subtropical Florida, USA, fire historically occurred primarily at the transition from the dry to wet season (early wet season: April to June) when dry fuel accumulation coincides with a high incidence of lightning. We investigated the effects of fire frequency and season on endangered Florida bonneted bats (Eumops floridanus [G.M. Allen, 1932]), a species endemic to a region that evolved with frequent fires.

Results: We surveyed bat activity acoustically in 149 sites in fire-dependent vegetation communities (pine flatwoods and prairies), and evaluated the effects of fire frequency and seasonality, using burn records from the previous 18 years. Variation in bat activity was best explained by both fire frequency and season: bat activity decreased with early wet season (April to June) burn interval and increased with dry season (November to March) burn interval. Bat activity and foraging activity were highest in sites burned at $>3$ - to 5-year intervals during the early wet season.

Conclusion: Fires during the historic fire season at a moderate frequency ( $>3$ to $5 \mathrm{yr}$ ) appear to optimize habitat for bats in both pine flatwoods and prairies, likely through increases in roosts, flight space, and insect prey availability. It appears that Florida bonneted bats are fire-adapted and benefit from prescribed burn programs that closely mimic historical fire regimes. We encourage consideration of both fire frequency and seasonality when managing ecosystems with fire.
\end{abstract}

Keywords: acoustic surveys, endangered species, Eumops floridanus, fire seasonality, Florida bonneted bats, foraging ecology, prescribed burning, South Florida

\footnotetext{
* Correspondence: ecbraun@ufl.edu

${ }^{1}$ Department of Wildlife Ecology and Conservation, University of Florida, 110

Newins-Ziegler Hall, Gainesville, FL 32611, USA

Full list of author information is available at the end of the article
} 


\section{Resumen}

Antecedentes: La supresión de incendios ha alterado las comunidades ecológicas a nivel global. Los regímenes de quemas prescriptas son esfuerzos para restaurar el funcionamiento de ecosistemas dependientes de fuego mediante la imitación de los regímenes naturales de fuego. Aunque la frecuencia de incendios es ampliamente reconocida como una componente de los regímenes de fuego, la importancia de la estacionalidad de los mismos para la biodiversidad es menos clara, aunque parece tener un rol crítico para una variedad de taxones especialmente en las planicies costeras de Norte América. En la Florida subtropical, EEUU, históricamente el fuego ha ocurrido en la transición entre la estación seca y la húmeda (estación húmeda temprana: abril a junio), cuando la acumulación de combustibles secos coincide con una gran incidencia de rayos. Investigamos los efectos de la frecuencia y la estación del fuego sobre el murciélago con bonete de Florida (Eumops floridanus [G.M. Allen, 1932]), una especie que se encuentra en peligro de extinción y es endémico de una región que evolucionó con incendios frecuentes.

Resultados: Evaluamos acústicamente la actividad del murciélago en 149 sitios en comunidades vegetales dependientes de fuego (bosques de pino de llanura y praderas) y evaluamos los efectos de la frecuencia del fuego y la estacionalidad, usando registros de quema de los 18 años anteriores. La variación en la actividad de los murciélagos fue mayormente explicada por la combinación de la frecuencia y la estacionalidad de los incendios: la actividad de los murciélagos decreció con el intervalo de incendios en la estación húmeda temprana (abril a junio) y se incrementó con el intervalo de incendios de la estación seca (noviembre a marzo). La mayor actividad de los murciélagos y su actividad forrajera fue en sitios quemados a intervalos $>3$ a 5 años durante la estación húmeda temprana.

Conclusiones: Los incendios que ocurren durante la estación histórica del fuego y a una frecuencia moderada ( $>3$ a 5 años) parecen optimizar el hábitat para los murciélagos tanto en bosques de pino de llanura como en praderas de Florida, probablemente por un incremento en los lugares de percheo para descanso, en el espacio para volar, y en la disponibilidad de insectos de presa. Parece entonces que los murciélagos con bonete de Florida están adaptados al fuego, y se benefician de los programas de quemas prescriptas que se asemejan mucho a los incendios históricos. Exhortamos se considere tanto la frecuencia de los incendios como su estacionalidad al manejar ecosistemas con quemas prescriptas.

\section{Abbreviations}

BICY: Big Cypress National Preserve BWWMA: Fred C. Babcock-Webb Wildlife Management Area FPNWR: Florida Panther National Wildlife Refuge FSPSP: Fakahatchee Strand Preserve State Park

\section{Background}

Fire is a critical process in maintaining and shaping many of the planet's biomes (Bond et al. 2004; Bond and Keeley 2005). Anthropogenic suppression of fire often leads to altered ecosystems via shifts in vegetation structure and species assemblages (Waldrop et al. 1992; Lorimer 2001; Nowacki and Abrams 2008; Darracq et al. 2016). To restore vegetation structure, species assemblages, and ecological function to fire-suppressed ecosystems, fire has been widely reintroduced through prescribed burn programs. However, the success of fire restoration efforts requires an understanding of how fires historically burned across the landscape such that prescribed fire can be applied to mimic those conditions in which fire-adapted species evolved (Bond et al. 2004; Platt et al. 2015).

Depending on their evolutionary history, particular patterns of burning - or fire regimes - can enhance or suppress populations of vertebrates (Darracq et al. 2016). Two key characteristics of fire regimes are fire frequency and season. Variation in these characteristics influences the intensity, extent, and ecological consequences of fire regimes (Knapp et al. 2009; Fill et al. 2012). The season in which fires historically occurred was typically when the greatest frequency of lightning strikes or indigenous human-induced fires coincided with an accumulation of flammable fuels, leading to greater fire spread (Snyder 1991; Knapp et al. 2009). However, many prescribed burns are conducted outside the historical fire season due to operational and liability constraints (Knapp et al. 2009; Hardin 2010). Disagreement remains regarding the ecological benefits conferred by burning within the historical fire season versus simply maintaining an appropriate fire frequency (time interval between fire events) (Hiers et al. 2000; Brockway and Lewis 2004; Robertson and Hmielowski 2014; Platt et al. 2015). This disagreement is likely because some taxa respond to burn season, while others respond to frequency, and the responses of most vertebrates appear to be indirectly related to fire through changes to vegetation structure (Russell et al. 1999; Kirkpatrick et al. 2006; Knapp et al. 2009).

One region in which fire ecologists and land managers are trying to better understand how variation in fire regimes influences wildlife populations is the North American Coastal Plain (Knapp et al. 2009). This region is a global hotspot of biodiversity and lightning (Noss et al. 2015, Nowacki and 
Abrams 2015), with over $85 \%$ of endemic plant species associated with fire-dependent communities (Estill and Cruzan 2001; Noss et al. 2015), and a variety of taxa exhibiting positive responses to fires conducted during the historical fire season (Knapp et al. 2009). Like other endemic wildlife species in the region, the federally endangered Florida bonneted bat (Eumops floridanus [G.M. Allen, 1932]) may be particularly sensitive to changes in fire regimes. Endemic to South Florida, USA, the Florida bonneted bat is a large subtropical bat (Ober et al. 2017b) whose entire geographic range occurs within this fire-adapted landscape. Although it appears to use fire-dependent vegetation communities for roosting (Belwood 1992; Angell and Thompson 2015; Braun de Torrez et al. 2016) and foraging (Bailey et al. 2017; Braun de Torrez et al. 2018b), and may actually be attracted to recently burned areas (Braun de Torrez et al. 2018a), we know little about how fire regimes influence this species on a broader scale. Because Florida bonneted bats do not migrate or hibernate, and likely have an extended period of reproduction in which non-volant young are present in roosts for much of the year (Ober et al. 2017a), the habitats of these bats are exposed to fire management year round. Bats in other regions appear to tolerate or benefit from certain aspects of fire (Loeb and Waldrop 2008; Buchalski et al. 2013; Cox et al. 2016; Lacki et al. 2017; Austin et al. 2018), but we still have a limited understanding of how specific components of fire regimes, such as frequency or season of fires, influence bats over the long-term (Perry 2012). Fire may have direct positive effects on bats by opening flight space under the canopy and creating new snags and cavities in live trees for roosting (Boyles and Aubrey 2006; Armitage and Ober 2012; O'Keefe and Loeb 2017). Or, fire may harm bats through destruction of roost trees (Morrison and Raphael 1993; Rodrigue et al. 2001; Dickinson et al. 2010). Fire may also indirectly affect bats by altering their insect prey base (Swengel 2001; Lacki et al. 2009; Armitage and Ober 2012; Perry 2012; Cox et al. 2016).

We investigated the relationship between fire regimes and Florida bonneted bat activity (a metric of relative habitat use) within fire-dependent vegetation communities to determine effective long-term burn management strategies for this critically endangered species. Because Florida bonneted bats have evolved in a region adapted to fire, we hypothesized that these bats would select habitat based on both the frequency and season of fires. We predicted that bat activity would increase with increasing burn frequency, particularly with burns occurring in the early wet season that mimic lightning-strike fires.

\section{Methods}

\section{Study areas}

We conducted research in 2015 and 2016 in four conservation areas within the core range of Florida bonneted bats in Florida, USA (USFWS 2013; Fig. 1): Big Cypress National
Preserve (BICY; 720000 acres in Collier, Miami-Dade, and Monroe counties, managed by National Park Service) Fakahatchee Strand Preserve State Park (FSPSP; 74000 acres in Collier County, managed by Florida Department of Environmental Protection), Fred C. Babcock-Webb Wildlife Management Area (BWWMA; 66000 acres in Charlotte County, managed by Florida Fish and Wildlife Conservation Commission), and Florida Panther National Wildlife Refuge (FPNWR; 26400 acres in Collier County, managed by US Fish and Wildlife Service). These study areas experience a range of fire regimes and contain a mix of slash pine (Pinus elliottii var. densa Little \& Dorman) flatwoods, cypress (Taxodium ascendens Brongn. and T. distichum [L.] Rich) communities, freshwater prairies, ponds, and hardwood hammocks. We focused on two fire-maintained vegetation communities: upland pine flatwoods (mesic, hydric), and prairies (wet, dry, marl). Recommended prescribed fire return intervals for these vegetation communities are: dry prairie ( 1 to 2 years), wet prairie ( 2 to 3 years), pine flatwoods ( 2 to 4 years), and marl prairie (2 to 10 years) (Florida Natural Areas Inventory 2010).

Within the subtropical climate of South Florida, there are two primary seasons characterized by precipitation and temperature: dry and wet seasons (Duever et al. 1994; Slocum et al. 2010). A third season, the historical fire season (or the early wet season), occurs at the transition of the dry and wet seasons when conditions are most favorable for fire spread (Platt et al. 2015). During this season (April-June), the number and extent of lightning-caused and anthropogenic wildfires are much greater than the rest of the year, likely similar to fires occurring during pre-Columbian times (Snyder 1991). High temperatures, frequent lightning, and an accumulation of low-moisture fuels combined with the onset of summer rains and vegetation in the active growth phase contribute to a period when the ecological benefits of burning may be highest (Knapp et al. 2009). Burning in this season tends to be most effective at controlling understory woody biomass and regenerating herbaceous plant cover (Robbins and Myers 1992; Waldrop et al. 1992; Streng et al. 1993). In contrast, fires during the dry season tend to favor woody plant regeneration due to the ability of such plants to mobilize carbohydrates stored in roots while plants are dormant (Robertson and Hmielowski 2014).

\section{Experimental design}

We used acoustic surveys to sample Florida bonneted bat activity across a landscape exposed to varying fire regimes. Acoustic surveys are routinely used to monitor patterns in bat activity and habitat use (Hayes et al. 2009; Parsons and Szewczak 2009). They are particularly effective for high-flying species not easily captured, such as Florida bonneted bats (Braun de Torrez et al. 2017), which have distinct, high-intensity echolocation calls 


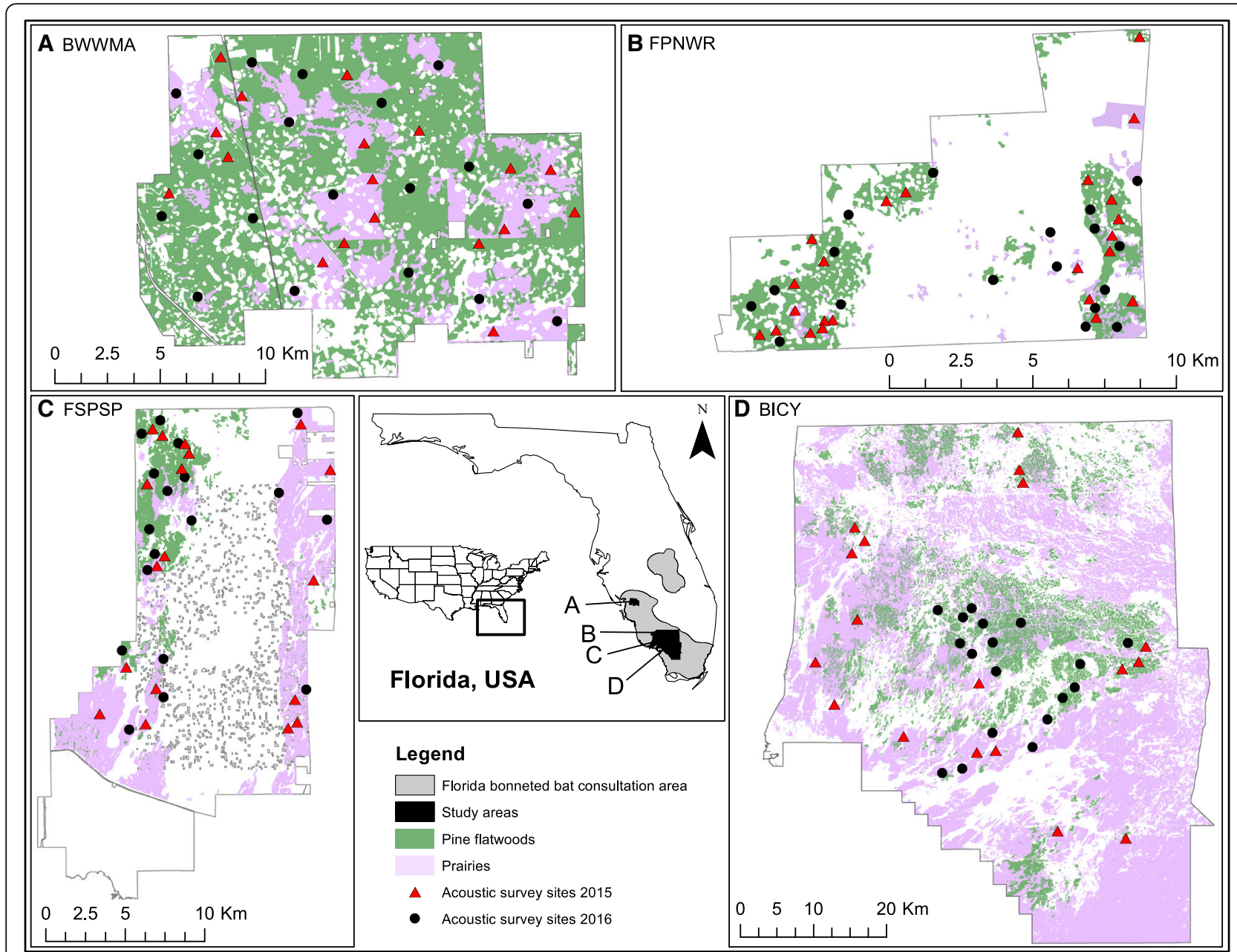

Fig. 1 Four conservation areas in Florida, USA, where we conducted acoustic surveys to evaluate effects of prescribed burning on activity of Florida bonneted bats, Eumops floridanus, in 2015 and 2016: (a) Fred C. Babcock-Cecil M. Webb Wildlife Management Area (BWWMA), (b) Florida Panther National Wildlife Refuge (FPNWR), (c) Fakahatchee Strand Preserve State Park (FSPSP), and (d) Big Cypress National Preserve (BICY). Gray shading depicts the consultation area for Florida bonneted bats as defined by the United States Fish and Wildlife Service (USFWS 2013)

(Belwood 1992; Bailey et al. 2017). We assumed that sites with greater activity received greater use by bats (Frick 2013).

We selected survey sites using a stratified random approach. We used ArcMap v10.2.2 (Esri, Redlands, California, USA), regional land cover maps (Florida Cooperative Land Cover Map v3.1), and 18 years of fire history records obtained from land managers to calculate historical fire frequencies across our study areas. We categorized each site as belonging to one of the following fire frequency categories: high frequency (1- to 3-year fire return interval), moderate frequency ( $>3$ - to 5-year fire return interval), and low frequency (>5-year fire return interval) (Darracq et al. 2016). We surveyed 149 sites stratified by fire frequency (77 in 2015, 72 in 2016; Fig. 1). In each study area, we typically surveyed 18 sites each year (9 in pine flatwoods and 9 in prairies). We randomly selected sites $\geq 100 \mathrm{~m}$ from the edge of each fire management unit or vegetation community, and $\geq 300 \mathrm{~m}$ from all other sites. We surveyed six sites simultaneously in each study area that represented each vegetation and fire frequency category, then moved to the next six sites until all sites were surveyed. To account for temporal variation (Hayes et al. 2009), we surveyed each site for two consecutive nights four times between January and July, with each survey separated by $\geq 21$ nights. This yielded eight detector survey nights per site for a total of 1192 detector nights (149 sites $\times 8$ nights).

\section{Acoustic surveys and species identification}

We conducted acoustic surveys using full spectrum Song Meter SM3BAT detectors and external SM3-U1 ultrasonic microphones (Wildlife Acoustics, Inc., Maynard, Massachusetts, USA), extended to $3 \mathrm{~m}$ above ground level. Once per month, we used an Ultrasonic Calibrator (Wildlife Acoustics, Inc.) to verify microphone sensitivity 
and system performance. To maximize the quality of recordings, we located detectors away from vegetative clutter (Britzke et al. 2013; Loeb et al. 2015). We programmed detectors to record from $30 \mathrm{~min}$ before sunset to $30 \mathrm{~min}$ after sunrise and defined each recorded file as a sequence of calls separated by $\geq 3 \mathrm{~s}$ and lasting $\leq 15 \mathrm{~s}$. We used Kaleidoscope Pro 3.14B (Wildlife Acoustics, Inc.) for automated noise (non-bat ultrasound) filtering, initial species classification, and to manually review the spectrograms of acoustic files. We identified all files that contained $\geq 2$ bat calls from Florida bonneted bats and used the number of such files per night as an index of bat activity (Britzke et al. 1999; Tibbels and Kurta 2003; Davidai et al. 2015). We further examined all files identified as Florida bonneted bats to classify those containing feeding buzzes, as a measure of foraging activity (Fenton 1970; Coleman and Barclay 2013). To reduce subjectivity, two researchers independently confirmed all manually validated files (program settings and call identification protocol; Additional file 1). We eliminated all acoustic files associated with nights when data were not recorded throughout the entire night due to equipment malfunction (10 detector nights).

\section{Fire characteristics}

We used ArcGIS and the statistical software R (v. 3.3.3) with R studio (v. 0.98.1102) (R Core Team 2017) to calculate the number of fires (wildfires or prescribed burns) that occurred at each survey site over the previous 18 years. Fires were only counted once per season (i.e., a multi-day burn was considered one fire) if they were $>40$ ha and considered to be successful by fire managers. We calculated BurnInterval (mean number of years between burns) and TimeSinceLastBurn (number of years since the last burn); if no burns occurred at a site during the 18-year period, we assigned a value of 20 years for both variables. We assessed seasonality using operational definitions of three seasons from studies characterizing burn seasons in the region according to rainfall and fire spread patterns: wet season (1 June to 1 November), dry season (2 November to 31 March), and early wet season (1 April to 30 June) (Slocum et al. 2010; Platt et al. 2015). Although onset dates and duration for these seasons vary annually depending on climate conditions, we selected date ranges that were as consistent as possible with the dates that local burn managers considered the start and end of each season across our study areas (M. Wright, BICY, Ochopee, Florida, USA, personal communication; G. Suszek, FPNWR, Immokalee, Florida, USA, personal communication; S.Houseknect, FSPSP, Copeland, Florida, USA, personal communication; M. Kemmerer, BWWMA, Punta Gorda, Florida, USA, personal communication). For each site, we assigned the season of the last burn and calculated BurnInterval and TimeSinceLastBurn for burns occurring during each season. Again, if no burns occurred at a site during the 18-year period within a given season, we assigned a value of 20 years for both variables. Historical data from FSPSP, FPNWR, and BWWMA were recorded according to distinct fire management units; thus, we calculated fire variables for each unit. Data from BICY consisted of GIS shapefiles representing the estimated area burned by each fire; thus, we calculated burn frequency at each site based on the number of overlapping burn polygons.

\section{Statistical analyses}

We conducted all graphical and statistical analyses using R. All reported errors are standard error of the mean $( \pm S E)$. To evaluate relative habitat use by Florida bonneted bats in relation to fire regimes, we quantified Florida bonneted bat activity (number of call files) and foraging activity (number of feeding buzz files) detected per night at each site. We first tested for spatial autocorrelation among sites using a Mantel test (permutations: 9999; Mantel 1967). We found no indication of spatial autocorrelation $(Z=0.021, P=$ 0.32 ), and thus pooled all sites together for further analyses.

We used generalized linear mixed-effects models (GLMMs; function glmmadmb from $\mathrm{R}$ package glmmADMB; Skaug et al. 2012) with "site" (detector location) as a random effect, which accounted for multiple survey nights at each detector site. We first tested for an effect of survey year $(2015,2016)$ or vegetation community (pine flatwoods, prairies) on Florida bonneted bat activity using a likelihood ratio test (function anova from $R$ stats package); as there was no effect of either variable (year: $X=0.12, P=0.729$; vegetation community: $X=1.42$, $P=0.233$ ), we pooled all survey data together and did not include these variables in our final models. We fit a null model and alternative models to a negative binomial distribution (zero inflated) with the following predictors: BurnInterval, TimeSinceLastBurn for all burns, and for burns conducted during each season (WetBurnInterval, TimeSinceLastWetBurn, DryBurnInterval, TimeSinceLastDryBurn, EarlyWetBurnInterval, TimeSinceLastEarlyWetBurn, LastBurnSeason; see Table 1). We created a suite of 40 models that included biologically relevant combinations of single variables, and additive, interactive, and quadratic fixed effects. To avoid collinearity, we only included predictor variables in the same model that had correlation coefficients $<|0.5|$ (Spearman rank correlation matrices; Booth et al. 1994, Zuur et al. 2009). We used Akaike's Information Criterion (AIC) and Akaike weights $\left(\omega_{\mathrm{i}}\right)$ to determine the relative support for each model (Burnham and Anderson 2002). If models had equivalent support ( $\leq$ $2 \Delta$ AIC), we selected the model with the fewest parameters and calculated evidence ratios (ratios of Akaike weights [ER]), which indicate the likelihood of one model versus another (Burnham and Anderson 2002). All parameters were estimated using maximum likelihood (ML) and 
Table 1 Descriptions of variables used in generalized linear mixed-effects models explaining Florida bonneted bat (Eumops floridanus) acoustic activity relative to a landscape gradient of burn regimes

\begin{tabular}{lll}
\hline Variable type & Variable name & Variable description \\
\hline Response & BatActivity & Florida bonneted bat acoustic files recorded per night \\
Response & ForagingActivity & Florida bonneted bat acoustic files recorded per night \\
Random effect & Site & that contain feeding buzzes \\
Fixed effect & Burnlnterval & Acoustic survey location \\
Fixed effect & WetBurnInterval & Mean number of years between burns conducted during \\
Fixed effect & DryBurnlnterval & any season \\
Fixed effect & EarlyWetBurnlnterval & Mean number of years between wet season burns \\
Fixed effect & TimeSinceLastBurn & Mean number of years between dry season burns \\
Fixed effect & TimeSinceLastWetBurn & Mean number of years between early wet season burns \\
Fixed effect & TimeSinceLastDryBurn & Number of years since last burn conducted during any \\
Fixed effect & TimeSinceLastEarlyWetBurn & season \\
Fixed effect & LastBurnSeason & Number of years since last wet season burn \\
\hline
\end{tabular}

Laplace approximations to allow for model comparisons (Bolker et al. 2009; Pinheiro et al. 2018).

To evaluate the effect of fire regime on bat activity in a context relevant to existing prescribed burn management programs, we divided the continuous burn interval variables that were included in our top model into three burn interval categories: 1 to $3,>3$ to 5 , and $>5$ (Florida Natural Areas Inventory 2010; Darracq et al. 2016). We constructed a GLMM with burn interval category as the predictor and bat activity as the response. To assess if bats were foraging differentially among sites in different burn interval categories, we also constructed a GLMM with foraging activity as the response. We tested the effect of categorical predictors (EarlyWetBurnInterval and DryBurnInterval) by using a likelihood ratio test to compare two nested models (LRT, function anova from $\mathrm{R}$ stats package; significance threshold $\alpha=0.05$ ). We conducted Tukey pairwise comparisons between levels of significant factors using the function glht ( $\mathrm{R}$ package multcomp), which adjusts significance values for multiple comparisons.

\section{Results}

We identified 238841 acoustic files that contained bat call sequences. Of these, we identified 4783 files that contained Florida bonneted bat calls $(2.0 \%$ of total bat files). We detected Florida bonneted bats at 145 of the 149 detector sites and on $65 \%$ of detector nights. Mean Florida bonneted bat activity was $4.04 \pm 0.21$ files per night, and mean foraging activity per night was $0.07 \pm$ 0.01 feeding buzzes per night.

The best model that explained Florida bonneted bat activity included two fixed effects: EarlyWetBurnInterval and DryBurnInterval $\quad\left(\triangle \mathrm{AIC}=0.0, \quad \omega_{\mathrm{i}}=0.51 ; \quad \mathrm{ER}=5.1\right.$;
Table 2). As we predicted, EarlyWetBurnInterval was negatively associated with bat activity $\left(-0.03 \pm 0.01\right.$ files night $^{-1}$, $P=0.015$; Fig. 2a). In contrast, DryBurnInterval exhibited a quadratic relationship in which it was positively associated from 0 to $\sim 13$ years $(9.03 \pm 2.97, P=0.002)$ and negatively associated after $\sim 13$ years $\left(-6.78 \pm 2.91\right.$ files night $^{-1}, P=$ 0.020; Fig. 2a). In contrast to what we predicted, BurnInterval and TimeSinceLastBurn were not included in the top models and were not significant predictors when tested in single variable models (BurnInterval: $0.01 \pm 0.02$ files night $^{-1}$, $P=0.49, \triangle \mathrm{AIC}=18.9, \omega_{\mathrm{i}}=0.00$; TimeSinceLastBurn: -0.04 \pm 0.03 files night $^{-1}, P=0.200, \Delta \mathrm{AIC}=17.7, \omega_{\mathrm{i}}=0.00$ ).

When we partitioned the two predictors in our best model into categories relevant to burn management programs, we found that bat activity significantly differed among the three burn interval categories for each of the two seasons (EarlyWetBurnInterval LRT: $\chi^{2}$ $=10.98, P=0.004 ;$ DryBurnInterval LRT: $\chi^{2}=13.78, P$ $=0.001)$. Bat activity was higher in sites burned during the early wet season at a moderate frequency $(>3-$ 5 years) than at low frequencies ( $>5$ years; $\beta=0.94$ \pm 0.29 files night $^{-1}, P=0.003$ ), with no significant differences between the other pairwise category comparisons (Fig. 3a). Bat activity was higher in sites burned during the dry season at a low frequency than moderate $(B=$ $0.53 \pm 0.22$ files night $\left.^{-1}, P=0.044\right)$ and high frequencies $\left(B=0.80 \pm 0.24\right.$ files night $\left.^{-1}, P=0.002\right)$, with no significant difference between moderate and high frequencies $\left(ß=0.27 \pm 0.33\right.$ files night $^{-1}, P=0.676$; Fig. $\left.3 \mathrm{~b}\right)$. Season and frequency of burns similarly explained variation in foraging activity (EarlyWetBurnInterval LRT: $\chi^{2}=6.53$, $P=0.038$; DryBurnInterval LRT: $\left.X^{2}=6.75, P=0.034\right)$, although detections of feeding buzzes were low $(n=80)$. 
Table 2 Alternative models (generalized linear mixed-effects models; negative binomial distribution) and predictor variables explaining Florida bonneted bat (Eumops floridanus) activity across 149 sites. Number of parameters (K), difference between Akaike Information Criteria (AIC) score of each alternative model and model with the lowest AIC score $(\triangle \mathrm{AIC})$, and Akaike weights $\left(\omega_{\mathrm{i}}\right)$ are listed for the top five models within 5 AAIC. All data were collected in 2015 and 2016 in South Florida, USA

\begin{tabular}{llll}
\hline Model & $\mathrm{K}$ & $\Delta$ AIC & $\omega_{\mathrm{i}}$ \\
\hline DryBurnInterval^2+EarlyWetBurnInterval & 6 & 0.0 & 0.51 \\
DryBurnInterval + EarlyWetBurnInterval & 5 & 3.3 & 0.10 \\
DryBurnInterval^2 & 5 & 3.9 & 0.07 \\
DryBurnInterval + EarlyWetBurnInterval + TimeSinceLastBurn & 6.0 & 4.07 \\
DryBurnInterval*TimeSinceLastBurn & 6 & 5.0 & 0.04 \\
\hline
\end{tabular}

Foraging activity was higher in sites burned during the early wet season at a moderate frequency than at a low frequency $\left(\beta=1.06 \pm 0.46\right.$ files night $^{-1}, \quad P=0.048$; Additional file 2), with no significant differences between the remaining pairwise comparisons. There were no significant pairwise differences in foraging activity among any burn interval categories for burns conducted during the dry season.

\section{Discussion}

Fire frequency explained variation in activity of Florida bonneted bats only when considered in conjunction with the seasonal timing of the fires. This is in contrast to current thinking for many other wildlife taxa, for which fire frequency is considered to be more important than season (Knapp et al. 2009), including for small mammals (Kirkland et al. 1996; Keyser and Ford 2006). Overall activity and foraging activity of Florida bonneted bats were highest in sites burned at a moderate frequency ( $>3-$ to 5 -year burn interval) during the early wet season and a low frequency ( $>5$ years) during the dry season, which is consistent with the historical fire season and within the estimated fire frequencies for this fire-adapted region (Wade et al. 1980; Florida Natural Areas Inventory 2010; Platt et al. 2015). In contrast, burning frequently (1 to 5 years) primarily during the dry season appeared to

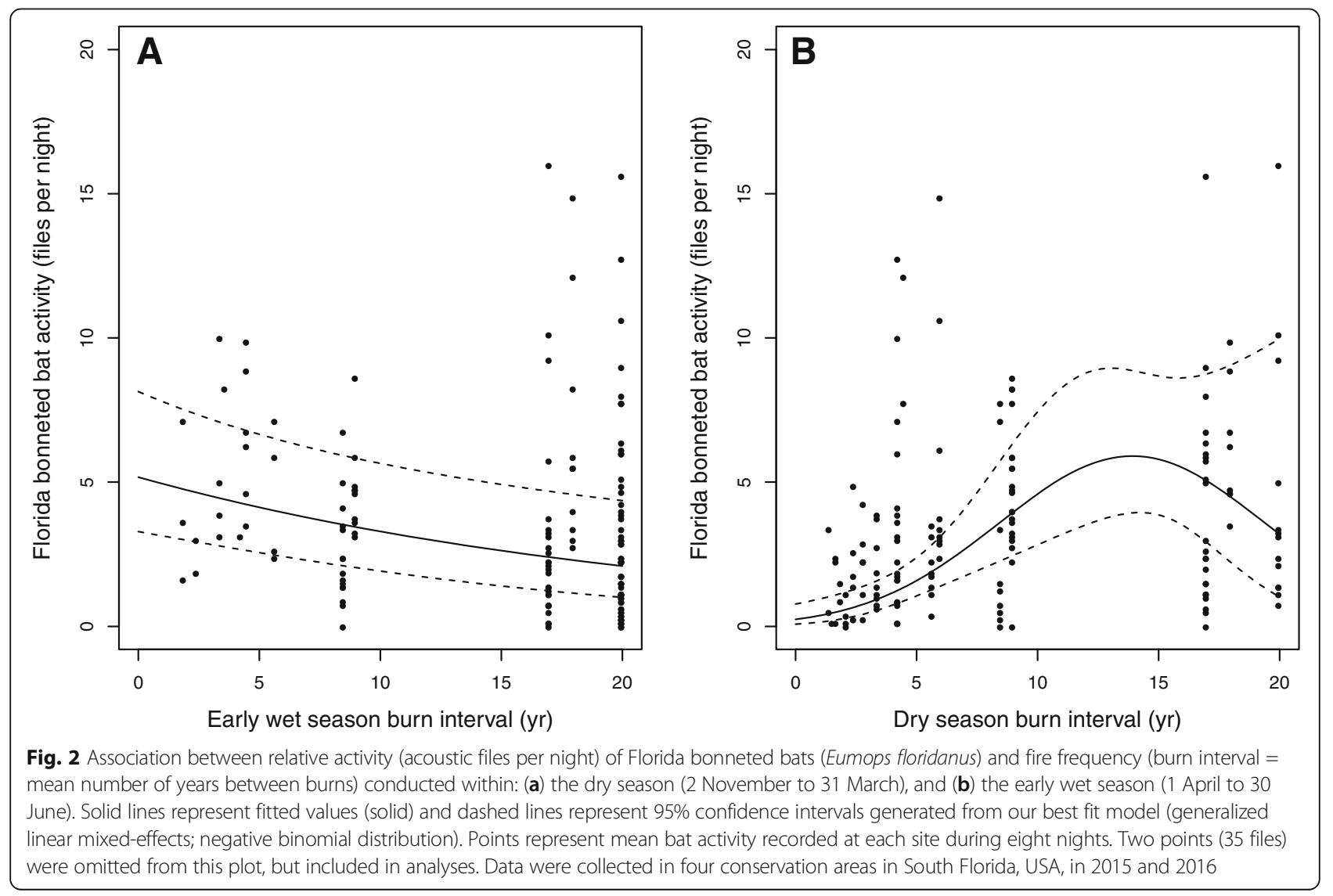




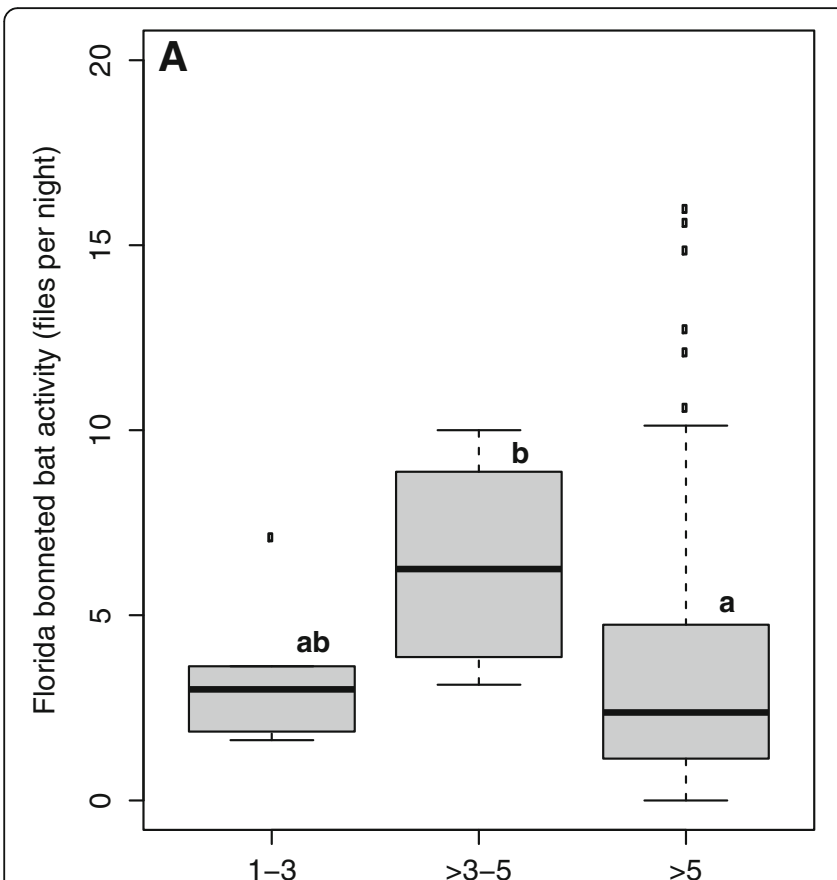

Early wet season burn interval (yr)

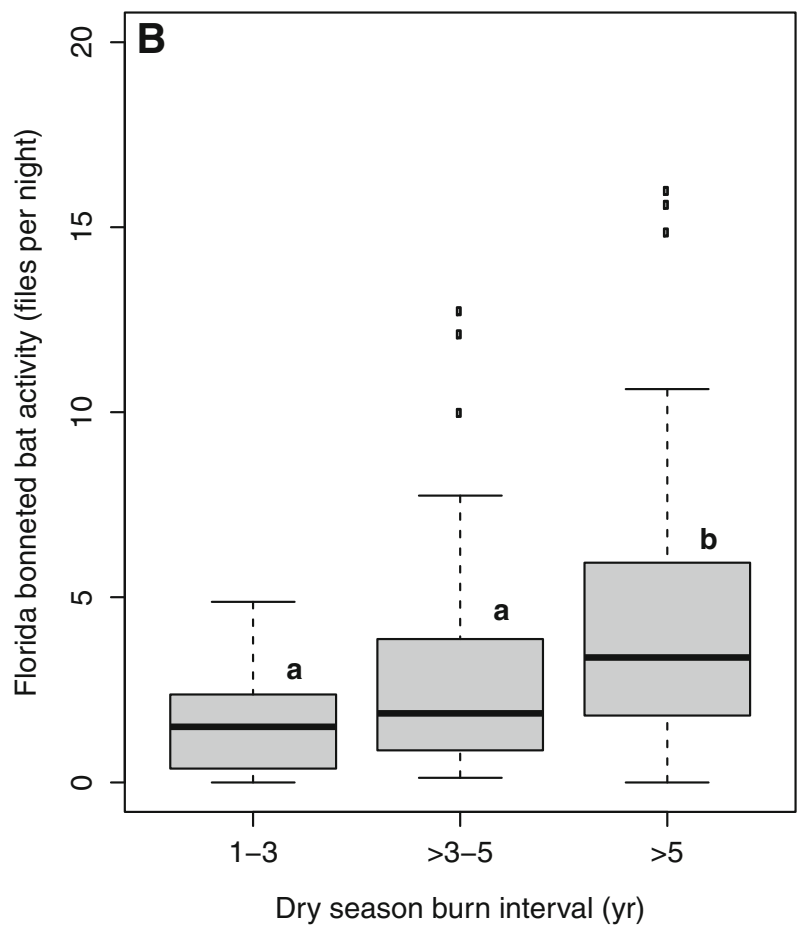

Dry season burn interval (yr)

Fig. 3 Relative activity (acoustic files per night) of Florida bonneted bats (Eumops floridanus) in 149 sites exposed to fire in three burn interval categories within: (a) the early wet season (1 April to 30 June), and (b) the dry season (2 November to 31 March). Letters indicate significant differences in bat activity among categories. Two points (35 files) were omitted from this plot, but included in analyses. Data were collected in four conservation areas in South Florida, USA, in 2015 and 2016

have negative effects on Florida bonneted bat activity; however, at very high burn intervals (> 13 years), activity again began to decline. Our results support previous studies demonstrating that fire-adapted species respond most favorably to burns conducted during the historical fire season (Knapp et al. 2009; Fill et al. 2012; Platt et al. 2015). Such patterns have also been documented within the North American Coastal Plain for herbaceous plants (e.g., wiregrass, Aristida stricta Michx.; Sparks et al. 1998), and several bird species (e.g., Bachman's sparrow, Peucaea aestivalis [M.H.K. Lichtenstein, 1823]; wild turkeys, Meleagris gallopavo [Linnaeus, 1758]; red-cockaded woodpecker, Picoides borealis [Vieillot, 1809]; Knapp et al. 2009). Consistent with our findings, Cox et al. (2016) documented higher overall bat activity in open longleaf pine (Pinus palustris Mill.) stands that were burned in the spring (late March) than in stands burned in the fall (October), but did not address this observed seasonal difference. Our study complements previous findings of short-term increases in Florida bonneted bat activity following prescribed fires (Braun de Torrez et al. 2018a), further implicating the importance of appropriate fire management for this species.

Fire regimes can have complex direct and indirect effects on volant organisms. Bats use habitat three-dimensionally for roosting and foraging; in response to fire, their habitat use could change spatially (e.g., shifts among local foraging areas across the landscape), vertically (e.g., shifts in flight altitudes), or temporally (e.g., shifts in the relative importance of various prey from one season to another). Thus, fire regimes may influence bats via a variety of mechanisms and time scales post fire. We hypothesize that the changes to vegetation structure and composition from burns conducted in the early wet season lead to long-term maintenance of habitat for bats across a landscape of pine flatwood and prairie communities through enhancement of a combination of three factors: open flight space, roost availability, and a robust insect community as prey. In the early wet season, conditions are most favorable for fire spread (Platt et al. 2015), regrowth of herbaceous vegetation, and suppression of woody biomass encroachment (Knapp et al. 2009; Fill et al. 2012). Within pine flatwoods, large-bodied, less maneuverable bat species such as Florida bonneted bats (Ober et al. 2017b) may respond favorably to this reduction of woody vegetative "clutter" as fire clears flight space below the canopy for less restricted foraging and access to roost trees (Armitage and Ober 2012). Further, fires during the early wet season can cause greater mortality and damage to overstory trees due to high temperatures and fully hydrated vascular tissues that reach lethal temperatures when burned (Brose and Van Lear 1999), which may lead to creation of more snags and tree 
cavities for roosting than are created during fires at other times of year. Finally, because structural complexity of vegetation influences niche space for insects (Murdoch et al. 1972; Knops et al. 1999), the insect community may respond favorably to the diverse herbaceous understory and ground cover associated with early wet season burns within both pine flatwoods and prairies. Arthropod communities may also experience fewer direct negative effects from burns conducted in the growing season, when more species are in a winged life stage and able to escape fires (Hermann et al. 1998). Based on our finding of no difference in bat activity between two structurally different vegetation communities, we suspect that either different mechanisms are acting in each community (roost availability and flight space in pine flatwoods and insect prey in prairies), or that change in insect prey is the primary driver across both vegetation types. Because these bats are likely capable of flying long distances each night (Ober et al. 2017b), they may select habitat on a broader landscape scale; for example, bats may select habitat in pine flatwoods due to the prevalence of roost sites but forage over adjacent prairies that experience similar burn histories.

Our finding that both bat activity and foraging activity were highest at a moderate burn interval of $>3$ to 5 years within the historical fire season aligns with a recent meta-analysis in longleaf pine ecosystems in which vertebrate species richness was maximized at such an interval (Darracq et al. 2016), although fire season was not differentiated in their analysis. Similarly, Dover and Payne (2018) found that sites burned at a moderate burn frequency (4 to 8 years) in longleaf pine forests in Alabama, USA, had higher insect abundance and diversity than sites burned at shorter and longer burn intervals. Leaving areas untreated by fire for 3 to 5 years allows for the development of pronounced hardwood midstory (Hiers et al. 2014; Lashley et al. 2014), which may increase structural heterogeneity and animal diversity relative to areas burned every 1 to 3 years. Higher foraging activity by Florida bonneted bats suggests that insect availability may similarly be greater in these sites. In contrast, shorter burn intervals may lead to a homogenous landscape with fewer resources, due to a sparse understory, less structure, and reduced establishment of fire-tolerant species (Ware et al. 1993; Engstrom et al. 2001; Lashley et al. 2014). Longer burn intervals, characterized by limited understory plant diversity and a dense hardwood midstory (Varner et al. 2005), may lead to reduced flight space for large bats in pine flatwoods (Armitage and Ober 2012). A tradeoff may also exist between creation of new cavity trees and destruction of existing snags, depending on the frequency and intensity of burns (Haslem et al. 2012; Stojanovic et al. 2016); burns conducted too frequently may destroy more cavity trees than are created or cause repeated roost disturbance that prevents colony establishment by bats (Perry 2012). Considering seasonality, sites that are burned at moderate frequencies within the early wet season may provide optimal habitat conditions for bats. Variables that we were unable to include in our models, such as abiotic (e.g., weather, hydrology) and biotic factors (e.g., bat and insect prey reproductive cycles), and variables associated with each burn (e.g., intensity, severity, extent, vegetation structure) may explain some of the remaining variation in our data. Accounting for these additional sources of variation may strengthen our mechanistic understanding of the relationships we observed.

\section{Conclusions}

We suggest that Florida bonneted bats are fire-adapted and benefit from prescribed burns that closely mimic historical fire regimes over the long-term. Restoring fire to fire-dependent ecosystems may improve habitat for this critically endangered species if burns are conducted when natural fires historically occurred across their range. We recommend that burns be conducted on a $>3$ - to 5-year burn interval during the early wet season in both pine flatwoods and prairies to provide the greatest benefit to this species. If burns must be conducted during the dry season, they should be conducted less frequently: $>5$-year burn interval, up to $\sim 13$ years, at which point bat activity may again decline. We encourage research on the mechanisms driving responses to fire regimes by Florida bonneted bats and bat assemblages worldwide to develop effective long-term conservation strategies for this understudied taxonomic group. Broadly, our results highlight the importance of considering seasonality, in addition to fire frequency, when evaluating the effects of fire on biodiversity.

\section{Additional files}

Additional file 1: Program settings and call identification protocol. Used for acoustic surveys measuring relative activity of Florida bonneted bat (Eumops floridanus) in sites of varying fire frequency across four study areas in South Florida, USA, in 2015 and 2016. (DOCX 642 kb)

Additional file 2: Relative foraging activity (feeding buzz acoustic files recorded per night) of Florida bonneted bats (Eumops floridanus) in 149 sites exposed to fire in three burn interval categories within: A) the early wet season (1 April to 30 June) and B) the dry season (2 November to 31 March). Letters indicate significant differences in bat foraging activity among categories. Data were collected in four conservation areas in South Florida, USA, in 2015 and 2016. (DOCX 34 kb)

Additional file 3: Acoustic and burn history data used in statistical analyses to assess the long-term effects of fire regimes on Florida bonneted bats (Eumops floridanus) in Florida, USA, in 2015 and 2016. (XLSX 182 kb)

\section{Acknowledgements}

We thank our amazing research technicians: K.A. Silas, M.A. Wallrichs, T. Rambo, C.L. Harding, A. Hammesfahr, and R. Sensor. We also thank the many staff, biologists, fire managers, and volunteers from Florida Fish and Wildlife Conservation Commission and each of our four study areas, including: C. Pope, M. Kemmerer, J. Birchfield, J. Myers, K. Smith, M. Danaher, B. Nottingham, G. Suszek, S. Houseknecht, M. Owen, S. Bass, L. Miller, B. Hart, M. Wright, S. Schultz, D. Jansen, R. Arwood, H. Nardi, W. Gurley, and many others. Finally, we appreciate contribution to our final manuscript by two anonymous reviewers. 


\section{Funding}

This research was funded by the Joint Fire Science Program (Project ID: 14-1-057). Equipment was contributed for the duration of the study by Everglades National Park, Big Cypress National Preserve, Naples Zoo, and Friends of the Florida Panther Refuge. The funding bodies had no role in the design of the study or collection, analysis, and interpretation of data or in writing the manuscript.

\section{Availability of data and materials}

The dataset supporting the conclusions of this article is included within the article and its additional file (Additional file 3).

\section{Authors' contributions}

HKO and RAM designed the study, secured project funding, and contributed to data analysis and manuscript writing. ECB contributed to final study design, coordinated and conducted data collection and analysis, and wrote the manuscript. All authors read and approved the final manuscript.

\section{Ethics approval}

All research followed American Society of Mammalogists guidelines for research on live animals (Sikes and Animal Care Use Committee of the American Society of Mammalogists 2016) and were in accordance with the following approved permits: University of Florida IACUC (\#201308070), USFWS (\#TE 23583B-1), FPNWR (\#41545-2016-IR), FWC (\#SUO-49616), BICY (\#BICY-2015-SCI-0001), and Florida Department of Environmental Protection (\#12161424).

\section{Consent for publication}

Not applicable.

\section{Competing interests}

The authors declare that they have no competing interests.

\section{Publisher's Note}

Springer Nature remains neutral with regard to jurisdictional claims in published maps and institutional affiliations.

\section{Author details}

${ }^{1}$ Department of Wildlife Ecology and Conservation, University of Florida, 110 Newins-Ziegler Hall, Gainesville, FL 32611, USA. ²Department of Wildlife Ecology and Conservation, University of Florida, 155 Research Road, Quincy, FL 32351, USA.

\section{Received: 6 June 2018 Accepted: 29 July 2018}

Published online: 27 December 2018

\section{References}

Angell, E., and G. Thompson. 2015. Second record of a natural Florida bonneted bat (Eumops floridanus) roost. Florida Field Naturalist 43: 185-188.

Armitage, D.W., and H.K. Ober. 2012. The effects of prescribed fire on bat communities in the longleaf pine sandhills ecosystem. Journal of Mammalogy 93: 102-114 https://doi.org/10.1644/11-MAMM-A-169.1.

Austin, L.V., A. Silvis, W.M. Ford, M. Muthersbaugh, and K.E. Powers. 2018. Bat activity following restoration prescribed burning in the central Appalachian upland and riparian habitats. Natural Areas Journal 38: 183-195 https://doi. org/10.3375/043.038.0208.

Bailey, A.M., H.K. Ober, A. Sovie, and R.A. McCleery. 2017. Impact of land use and climate on the distribution of the endangered Florida bonneted bat. Journal of Mammalogy 98: 1586-1593 https://doi.org/10.1093/jmammal/gyx117.

Belwood, J.J. 1992. Florida mastiff bat, Eumops glaucinus floridanus. In Rare and endangered biota of Florida. Volume 1. Mammals, ed. S.R. Humphrey, 216-223. Gainesville: University Press of Florida.

Bolker, B.M., M.E. Brooks, C.J. Clark, S.W. Geange, J.R. Poulsen, M.H.H. Stevens, and J.-S.S. White. 2009. Generalized linear mixed models: A practical guide for ecology and evolution. Trends in Ecology \& Evolution 24: 127-135 https://doi. org/10.1016/j.tree.2008.10.008.

Bond, W., and J. Keeley. 2005. Fire as a global 'herbivore': The ecology and evolution of flammable ecosystems. Trends in Ecology \& Evolution 20: 387-394 https://doi. org/10.1016/j.tree.2005.04.025.

Bond, W.J., F.I. Woodward, and G.F. Midgley. 2004. The global distribution of ecosystems in a world without fire. New Phytologist 165: 525-538.
Booth, G., M. Niccolucci, and E. Schuster. 1994. Identifying proxy sets in multiple linear regression: An aid to better coefficient interpretation. USDA Forest Service research paper INT-470. Ogden: Intermountain Research Station.

Boyles, J.G., and D.P. Aubrey. 2006. Managing forests with prescribed fire: Implications for a cavity-dwelling bat species. Forest Ecology and Management 222: 108-115 https://doi.org/10.1016/j.foreco.2005.09.024.

Braun de Torrez, E.C., H.K. Ober, and R.A. McCleery. 2016. Use of a multi-tactic approach to locate an endangered Florida bonneted bat roost. Southeastern Naturalist 15: 235-242 https://doi.org/10.1656/058.015.0204.

Braun de Torrez, E.C., H.K. Ober, and R.A. McCleery. 2018a. Activity of an endangered bat increases following prescribed burns. Journal of Wildlife Management: 1-9 https://doi.org/10.1002/jwmg.21481.

Braun de Torrez, E.C., H.K. Ober, and R.A. McCleery. 2018b. Critically imperiled forest fragment supports bat diversity and activity within a subtropical grassland. Journal of Mammalogy 99: 273-282 https://doi.org/10.1093/ jmammal/gyx169.

Braun de Torrez, E.C., S.T. Samoray, K.A. Silas, M.A. Wallrichs, M.W. Gumbert, H.K. Ober, and R.A. McCleery. 2017. Acoustic lure allows for capture of a highflying, endangered bat. Wildlfe Society Bulletin 41: 322-328 https://doi.org/10. 1002/wsb.778.

Britzke, E.R., E.H. Gillam, and K.L. Murray. 2013. Current state of understanding of ultrasonic detectors for the study of bat ecology. Acta Theriologica 58: 109-117 https://doi.org/10.1007/s13364-013-0131-3.

Britzke, E.R., K.L. Murray, B.M. Hadley, and L.W. Robbins. 1999. Measuring bat activity with the Anabat II system. Bat Research News 40: 1-5.

Brockway, D.G., and C.E. Lewis. 2004. Long-term effects of dormant-season prescribed fire on plant community diversity, structure and productivity in a longleaf pine wiregrass ecosystem. Forest Ecology and Management 96: 167-183 https://www.nrs.fs.fed.us/pubs/gtr/gtr-nrs-p-102papers/12perry-p-102.pdf.

Brose, P., and D. Van Lear. 1999. Effects of seasonal prescribed fires on residual overstory trees in oak-dominated shelterwood stands. Southern Journal of Applied Forestry 23: 88-93.

Buchalski, M.R., J.B. Fontaine, P.A. Heady, J.P. Hayes, and W.F. Frick. 2013. Bat response to differing fire severity in mixed-conifer forest California, USA. PLOS ONE 8: e57884 https://doi.org/10.1371/journal.pone.0057884.

Burnham, K.P., and D.R. Anderson. 2002. Model selection and multimodel inference: An information-theoretic approach. New York: Springer Science.

Coleman, J.L., and R.M.R. Barclay. 2013. Prey availability and foraging activity of grassland bats in relation to urbanization. Journal of Mammalogy 94: 1111-1122 https://doi.org/10.1644/12-MAMM-A-217.1

Core Team, R. 2017. R: A language and environment for statistical computing. Vienna: R Foundation for Statistical Computing.

Cox, M.R., E.V. Willcox, and P.D. Keyser. 2016. Bat response to prescribed fire and overstory thinning in hardwood forest on the Cumberland plateau, Tennessee. Forest Ecology and Management 359: 221-231 https://doi.org/10. 1016/j.foreco.2015.09.048

Darracq, A.K., W.W. Boone, and R.A. McCleery. 2016. Burn regime matters: A review of the effects of prescribed fire on vertebrates in the longleaf pine ecosystem. Forest Ecology and Management 378: 214-221 https://doi.org/10. 1016/j.foreco.2016.07.039

Davidai, N., J.K. Westbrook, J.P. Lessard, T.G. Hallam, and G.F. McCracken. 2015. The importance of natural habitats to Brazilian free-tailed bats in intensive agricultural landscapes in the winter garden region of Texas, United States. Biological Conservation 190: 107-114 https://doi.org/10.1016/j.biocon.2015.05.015.

Dickinson, M.B., J.C. Norris, A.S. Bova, R.L. Kremens, V. Young, and M.J. Lacki. 2010 Effects of wildland fire smoke on a tree-roosting bat: Integrating a plume model, field measurements, and mammalian dose-response relationships. Canadian Journal of Forest Research 40: 2187-2203 https://doi.org/10.1139/ X10-148.

Dover, J., and G. Payne. 2018. Survey of insect availability for foraging bats in the Shoal Creek district of Alabama's Talladega National Forest. Georgia Journal of Science 76 (1): 112.

Duever, M.J., J.F. Meeder, L.C. Meeder, and J.M. McCollom. 1994. The climate of South Florida and its role in shaping the Everglades ecosystem. In Everglades: The ecosystem and its restoration, ed. S.M. Davis and J.C. Ogden, 225-248. Delray Beach: St. Lucie Press.

Engstrom, R.T., L.K. Kirkman, and R.J. Mitchell. 2001. The natural history of the fire forest. The fire forest: Longleaf pine-Wiregrass ecosystem. Geogia Wildlife Federation 8: 5-17.

Estill, J.C., and M.B. Cruzan. 2001. Phytogeography of rare plant species endemic to the southeastern United States. Castanea 66: 3-23. 
Fenton, M.B. 1970. A technique for monitoring bat activity with results obtained from different environments in southern Ontario. Canadian Journal of Zoology 48: 847-851 https://doi.org/10.1139/z70-148.

Fill, J.M., S.M. Welch, J.L. Waldron, and T.A. Mousseau. 2012. The reproductive response of an endemic bunchgrass indicates historical timing of a keystone process. Ecosphere 3: 1-12 https://doi.org/10.1890/ES12-00044.1.

Florida Natural Areas Inventory. 2010. Guide to the natural communities of Florida: 2010 edition. Tallahassee: Florida Natural Areas Inventory.

Frick, W.F. 2013. Acoustic monitoring of bats, considerations of options for longterm monitoring. Therya 4: 69-78.

Hardin, E.D. 2010. Institutional history of prescribed fire in the Florida division of forestry: Lessons from the past, directions for the future. in: K.M. Robertson, K E.M. Galley, and R.E. Masters. Proceedings of the 24th tall timbers fire ecology conference-the future of fire: Public awareness, health, and safety. Tall Timbers Research Station, Tallahassee. 35-42.

Haslem, A., S.C. Avitabile, R.S. Taylor, L.T. Kelly, S.J. Watson, D.G. Nimmo, S.A. Kenny, K.E. Callister, L.M. Spence-Bailey, A.F. Bennett, and M.F. Clarke. 2012. Time-since-fire and inter-fire interval influence hollow availability for fauna in a fire-prone system. Biological Conservation 152: 212-221 https://doi.org/10. 1016/j.biocon.2012.04.007

Hayes, J.P., H.K. Ober, and R.E. Sherwin. 2009. Survey and monitoring of bats. In Ecological and behavioral methods for the study of bats, ed. T.H. Kunz and S. Parsons, 112-129. Baltimore: Johns Hopkins University Press.

Hermann, S.M.T.V.H., R.W. Flowers, L.A. Brennan, J.S. Glitzenstein, D.R. Streng, J.L. Walker, and R.L. Myers. 1998. Fire and biodiversity: Studies of vegetation and arthropods. In Transactions of the sixty-third north American wildlife and natural resources conference, ed. K.G. Wadsworth, 384-401. Washington, DC: Wildlife Management Institute.

Hiers, J.K., J.R. Walters, R.J. Mitchell, J.M. Varner, L.M. Conner, L.A. Blanc, and J. Stowe. 2014. Ecological value of retaining pyrophytic oaks in longleaf pine ecosystems. Journal of Wildlife Management 78: 383-393 https://doi.org/10. 1002/jwmg.676.

Hiers, J.K., R. Wyatt, and R.J. Mitchell. 2000. The effects of fire regime on legume reproduction in longleaf pine savannas: Is a season selective? Oecologia 125: 521-530 https://doi.org/10.1007/s004420000469.

Keyser, P.D., and W.M. Ford. 2006. Influence of fire on mammals in eastern oak forests. USDA Forest Service general technical report GTR-NRS-P-1. Newton Square: Northern Research Station.

Kirkland, G.L., H.W. Snoddy, and T.L. Amsler. 1996. Impact of fire on small mammals and amphibians in a central Appalachian deciduous forest. American Midland Naturalist 135: 253-260 https://doi.org/10.2307/2426707.

Kirkpatrick, C., C.J. Conway, and P.B. Jones. 2006. Distribution and relative abundance of forest birds in relation to burn severity in southeastern Arizona. Journal of Wildife Management 70: 1005-1012.

Knapp, E.E., B.L. Estes, and C.N. Skinner. 2009. Ecological effects of prescribed fire season: A literature review and synthesis for managers. USDA Forest Service general technical report PSW-GTR-224. Redding: Pacific Southwest Research Station.

Knops, J.M.D.T., N.M. Haddad, S. Naeem, C.E. Mitchell, J. Haarstad, M.E. Ritchie, K.M. Howe, P.B. Reich, E. Siemann, and J. Groth. 1999. Effects of plants species richness on invasion dynamics, disease outbreaks, insect abundances and diversity. Ecol Lett 2: 286-293 https://doi.org/10.1046/j.1461-0248.1999.00083.x.

Lacki, M.J., D.R. Cox, L.E. Dodd, and M.B. Dickinson. 2009. Response of northern bats (Myotis septentrionalis) to prescribed fires in eastern Kentucky forests. Journal of Mammalology 90: 1165-1175 https://doi.org/10.1644/08-MAMM-A-349.1.

Lacki, M.J., L.E. Dodd, N.S. Skowronski, M.B. Dickinson, and L.K. Rieske. 2017 Relationships among burn severity, forest canopy structure and bat activity from spring burns in oak-hickory forests. International Journal of Wildland Fire 26: 963-972.

Lashley, M.A., M.C. Chitwood, A. Prince, M.B. Elfelt, E.L. Kilburg, C.S. DePerno, and C.E. Moorman. 2014. Subtle effects of a managed fire regime: A case study in the longleaf pine ecosystem. Ecological Indicators 38: 212-217 https://doi. org/10.1016/j.ecolind.2013.11.006.

Loeb, S.C., T.J. Rodhouse, L.E. Ellison, C.L. Lausen, J.D. Reichard, K.M. Irvine, T.E. Ingersoll, J.T.H. Coleman, W.E. Thogmartin, J.R. Sauer, C.M. Francis, M.L. Bayless, T.R. Stanley, and D. Johnson. 2015. A plan for the north American bat monitoring program (NABat). USDA Forest Service general technical report SRS208. Asheville: Southern Research Station.

Loeb, S.C., and T.A. Waldrop. 2008. Bat activity in relation to fire and fire surrogate treatments in southern pine stands. Forest Ecology and Management 255: 3185-3192.
Lorimer, C.G. 2001. Historical and ecological roles of disturbance in eastern north American forests: 9,000 years of change. Wildlife Society Bulletin 29: 425-439.

Mantel, N. 1967. The detection of disease clustering and a generalized regression approach. Cancer Research 27: 209-220.

Morrison, M.L., and M.G. Raphael. 1993. Modeling the dynamics of snags. Ecological Applications 3: 322-330 https://doi.org/10.2307/1941835.

Murdoch, W.W., F.C. Evans, and C.H. Peterson. 1972. Diversity and pattern in plants and insects. Ecology 53: 819-829 https://doi.org/10.2307/1934297.

Noss, R.F., W.J. Platt, B.A. Sorrie, A.S. Weakley, D.B. Means, J. Costanza, and R.K. Peet. 2015. How global biodiversity hotspots may go unrecognized: Lessons from the north American coastal plain. Diversity and Distributions 21: 236-244 https://doi.org/10.1111/ddi.12278.

Nowacki, G.J., and M.D. Abrams. 2008. The demise of fire and "mesophication" of forests in the eastern United States. BioScience 58: 123-138 https://doi.org/10 1641/B580207.

Nowacki, G.J., and M.D. Abrams. 2015. Is climate an important driver of postEuropean vegetation change in the eastern United States? Global Change Biology 21: 314-334 https://doi.org/10.1111/gcb.12663.

O'Keefe, J.M., and S.C. Loeb. 2017. Indiana bats roost in ephemeral, fire-dependent pine snags in the southern Appalachian Mountains, USA. Forest Ecology and Management 391: 264-274 https://doi.org/10.1016/.jforeco.2017.01.036.

Ober, H.K., E.C. Braun de Torrez, J.A. Gore, A.M. Bailey, J.K. Myers, K.N. Smith, and R. A. McCleery. 2017b. Social organization of an endangered subtropical species, Eumops floridanus, the Florida bonneted bat. Mammalia 81: 375-383 https://doi.org/10.1515/mammalia-2015-0183.

Ober, H.K., E.C. Braun de Torrez, R.A. McCleery, A.M. Bailey, and J.A. Gore. 2017 a. Sexual dimorphism in the endangered Florida bonneted bat, Eumops floridanus (Chiroptera: Molossidae). Florida Scientist 80: 38-48.

Parsons, S., and J.M. Szewczak. 2009. Detecting, recording, and analyzing the vocalizations of bats. In Ecological and behavioral method for the study of bats, ed. T.H. Kunz and S. Parsons, Second ed., 91-111. Baltimore: Johns Hopkins University Press.

Perry, R.W. 2012. A review of fire effects on bats and bat habitat in the eastern oaks region. In Proceedings of the 4th fire in eastern oak forests conference. UDA Forest Service general technical report NRS-P-102, ed. D.C. Dey, M.C. Stambaugh, S.L. Clark, and C.J. Schweitzer, 170-191. Pennsylvania: Northern research Station Newton Square.

Pinheiro, J., D. Bates, S. DebRoy, D. Sarkar, and R. Development Core Team. 2018. NIme: Linear and nonlinear mixed effects models. R package version 3, 1-137. Vienna: R Foundation for Statistical Computing Available at https://CRAN.Rproject.org/package=nlme.

Platt, W.J., S.L. Orzell, and M.G. Slocum. 2015. Seasonality of fire weather strongly influences fire regimes in south Florida savanna-grassland landscapes. PLOS One 10: e0116952.

Robbins, L.E., and R.L. Myers. 1992. Seasonal effects of prescribed burning in Florida: A review. Tallahassee: Tall Timbers Research Station Miscellaneous Publication 8.

Robertson, K.M., and T.L. Hmielowski. 2014. Effects of fire frequency and season on resprouting of woody plants in southeastern US pine-grassland communities. Oecologia 174: 765-776 https://doi.org/10.1007/s00442-013-2823-4.

Rodrigue, J.L., T.S. Schuler, and M.A. Menzel. 2001. Observations of bat activity during prescribed burning in West Virginia. Bat Research News 42: 48-49.

Russell, K.R., D.H. Van Lear, and D.C. Guynn Jr. 1999. Prescribed fire effects on herpetofauna: Review and management implications. Wildlife Society Bulletin 27: $374-384$.

Sikes RS, Animal Care and Use Committee of the American Society of Mammalogists. 2016. 2016 guidelines of the American Society of Mammalogists for the use of wild mammals in research and education. Journal of Mammalogy 97: 663-688 https://doi.org/10.1093/jmammal/gyw078.

Skaug, H., D. Fournier, B. Bolker, A. Magnusson, and A. Nielsen. 2012. glmmADMB: Generalized linear mixed models using AD model builder. $R$ package version 0.8.0. <http://glmmadmb.r-forge.r-project.org/>. Accessed 21 July 2017.

Slocum, M.G., W.J. Platt, B. Beckage, S.L. Orzell, and W. Taylor. 2010. Accurate quantification of seasonal rainfall and associated climate-wildfire relationships. Journal of Applied Meteorology and Climatology 49: 2559-2573 https://doi.org/10.1175/2010JAMC2532.1.

Snyder, J.R. 1991. Fire regimes in subtropical South Florida. Proceedings of the Tall Timbers Fire Ecology Conference 17: 303-319.

Sparks, J.C., R.E. Masters, D.M. Engle, M.W. Palmer, and G.A. Bukenhofer. 1998. Effects of late growing-season and late dormant-season prescribed fire on herbaceous vegetation in restored pine-grassland communities. Journal of Vegetation Science 9: 133-142 https://doi.org/10.2307/3237231. 
Stojanovic, D., J. Webb nee Voogdt, M. Webb, H. Cook, and R. Heinsohn. 2016. Loss of habitat for a secondary cavity nesting bird after wildfire. Forest Ecology and Management 360: 235-241 https://doi.org/10.1016/j.foreco.2015. 10.040 .

Streng, D.R., J.S. Glitzenstein, and B. Platt. 1993. Evaluating effects of season of burn in longleaf pine forests: A critical literature review and some results from an ongoing long-term study. Proceedings of the Tall Timbers Fire Ecology Conference 18: 227-263.

Swengel, A.B. 2001. A literature review of insect responses to fire, compared to other conservation managements of open habitat. Biodivers Conserv 10: 1141-1169 https://doi.org/10.1023/A:1016683807033.

Tibbels, A.E., and A. Kurta. 2003. Bat activity is low in thinned and unthinned stands of red pine. Canadian Journal of Forest Reseach 33: 2436-2442 https:// doi.org/10.1139/×03-177.

USFWS [United States Fish and Wildlife Service]. 2013. Endangered and threatened wildlife and plants: Endangered species status for the Florida bonneted bat. Fed Regist 78 (191): 61004-61043.

Varner, J.M., D.R. Gordon, F.E. Putz, and J.K. Hiers. 2005. Restoring fire to longunburned Pinus palustris ecosystems: Novel fire effects and consequences for long-unburned ecosystems. Restoration Ecology 13: 536-544 https://doi.org/ 10.1111/j.1526-100X.2005.00067.x.

Wade, D., J. Ewel, and R. Hofstetter. 1980. Fire in South Florida ecosystems. USDA Forest Service general technical report SE-17. Asheville: Southeastern Forest Experiment Station https://doi.org/10.2737/SE-GTR-17.

Waldrop, T.A., D.L. White, and S.M. Jones. 1992. Fire regimes for pine-grassland communities in the southeastern United States. Forest Ecology and Management 47: 195-210 https://doi.org/10.1016/0378-1127(92)90274-D.

Ware, S., C. Frost, and P.D. Doerr. 1993. Southern mixed hardwood forest: The former longleaf pine forest. In Biodiversity of the southeastern United States: Lowland terrestrial communities, ed. W.H. Martin, S.G. Boyce, and A.C. Echternacht, 447-493. New York: Wiley

Zuur, A.F., E.N. Leno, N.J. Walker, A.A. Savaliev, and G.M. Smith. 2009. Mixed effects models and extensions in ecology with R. New York: Springer-Verlag.

\section{Submit your manuscript to a SpringerOpen ${ }^{\circ}$ journal and benefit from:}

- Convenient online submission

- Rigorous peer review

- Open access: articles freely available online

High visibility within the field

- Retaining the copyright to your article

Submit your next manuscript at $\boldsymbol{\nabla}$ springeropen.com 